\title{
THE EXPRESSIVE CAPACITY OF THE TIMBER FRAME
}

\author{
BRIT ANDRESEN \\ School of Geography, Planning and Architecture \\ Faculty of Engineering, Physical Sciences and Architecture \\ University of Queensland \\ QLD 4072, Australia \\ b.andresen@uq.edu.au
}

\begin{abstract}
Assembling for the first time a braced, timber frame as a freestanding structure, where no piece could be taken away without collapsing it, was surely a 'eureka' moment in architecture. The expressive potential of the timber frame can be argued to have led both to its development as well as to its later transfer and transformation.

It is the intention of this paper to present the braced frame of the medieval stave-church as the opportunity for expressing Christian 'church-like' qualities in pagan Norway - a part transformation in timber-rich Norway from the established practise of constructing stone churches in the south.

Six centuries later ecclesiologists sought medieval examples for the construction of wooden churches in colonial diocese - such as those in Canada and New Zealand where timber was plentiful. Several mid-C19th publications, such as The Reverend William Scott's paper "On Wooden Churches", raised awareness among ecclesiologists of the potential of medieval Scandinavian examples to contribute to the transformation of the wooden church in the colonies by transferring 'church-like' qualities to the utilitarian 'god box'.

The C19th wooden churches by R.G. Suter in Queensland are innovative examples of an ecclesiastical architecture in timber that takes advantage of the expressive potential of exposing the frame and the use of 'outside studding'.

There are direct transfers of these earlier techniques and technologies through the use of 'outside studding' and the exposed timber frame in the work of Andresen O'Gorman Architects. In this contemporary architectural practice techniques and technologies are transferred as much for the frame's expressive potential as for the pragmatic use of a renewable resource. Mooloomba House will be used as an example to identify conceptual ideas expressed through the timber frame rather than an explanation of the architectural project as a whole.
\end{abstract}

\section{Introduction}

It is the intention of this paper to show that a construction technique which permits the structure of a braced, timber frame to be made visible - revealing its parts as contributing to the whole yields expressive potential and opportunities for transfer and transformation of intentions in architecture. Visibility of the timber frame reveals for example the verticality of uprights 
(contributing direction, proportion, rhythm etc) and network of lineal timber members for example in a wall plane or as a spatial matrix (contributing degrees of enclosure, hierarchy, proportion etc). These properties also reveal a capacity for expressing formal and spatial character. And, whilst present in frame structures of other materials, properties of the timber frame offer great dimensional range (matchstick to log) and discernable material composition (fibres, knots) that further increase its expressive capacity.

Visibility of the timber frame is significant whether exposed on the interior, exterior or simultaneously on both sides of a structure. In the case of the medieval Norwegian basilica stave-church at Heddal the braced, timber frame is visible on the interior (floor, walls and openwork roof) with primary framing components also visible on the exterior walls. In the $19^{\text {th }}$ century church at Lutwyche by R.G. Suter the timber frame is exposed on the exterior (walls) and interior (openwork roof). In the contemporary Mooloomba House the timber frame is made visible on the interior and exterior (walls and roof).

In these three examples the conventional timber construction was transformed - initially by freeing the timber from the ground for the advantages of the 'above-ground', three dimensional, braced frame and then by exposing the timber frame with its matrix of members for the advantage of its expressive capacity.

\section{Timber frames in the Norwegian stave-church}

Development of the braced, timber frame of the medieval, Norwegian stave-church was stimulated by the desire to express Gothic ideals through interior and exterior verticality and allusion to 'heavenly mansions' in clustered gables on the exterior. Its fullest expression can be found in the basilica stave-church built during the $12^{\text {th }}$ and $13^{\text {th }}$-centuries (Gjone D5).

Of the estimated 750 stave-churches built in Norway over a five hundred year period from the late $10^{\text {th }}$ to the early $16^{\text {th }}$-centuries (Gjone D2) only twenty-seven have survived (Bugge and Norberg-Schulz 23) - their destruction largely brought about by social upheaval and neglect stave-churches ceased to be constructed in Norway after the Reformation when churches builders turned to horizontal log construction (Gjone D12).

North of the Alps, timber churches were once widely spread across Europe from the earliest times. In general terms, two principal timber construction techniques were geographically distributed; with horizontally laid log construction in eastern Europe and vertical stave construction in western and northern Europe (Gjone D1).

Only remnants of stave-churches built prior to mid- $11^{\text {th }}$-century have been found; namely at the church at Greenstead, Essex, England and the church of St Maria Minor in Lund, Sweden both built around the year 1000 and at Hemse Church in Gotland built during the first half of the $11^{\text {th }}$ century Gjone D2). The earliest church remnants reveal a timber construction of palisade walls, vulnerable to decay, made of oak timbers raised vertically, each connected by a loose filet and with posts set directly into the earth (Gjone D2).

Central to the successful construction of the $12^{\text {th }}$ and early $13^{\text {th }}$-century Norwegian basilica-type stave-church was the innovative, braced, timber frame supported above ground on four stone foundations. Structurally this was a radical transformation of the earlier construction where the timber posts were set into the ground. Freeing the timber entirely from the earth required the structure to be both conceived of, and built, as an integrated, freestanding, braced frame (Gjone D2).

In the Norwegian stave-church the frame is of fir and is typically exposed both on the outside and inside of the building. Buildings in the main group of stave-churches are characterized by a structural "system of free-standing inner posts, which define a lofty central space. The weight of the building rests on four points only: a rectangular frame under the floor is supported on four large stones placed where the beams cross each other." (Bugge and Norberg-Schulz 23).

The Norwegian basilica stave-church exterior and interior, despite its relatively modest dimensions to our eyes, would have appeared extraordinarily high and mysterious to congregations of the Middle Ages. The unpainted stave-church interior with its tall, dark forest of posts is spot-lit only by small, round openings set high in the upper walls. Its enclosing walls are cast in shadows dissolving the space into darkness intensifying its spatial mystery. The verticality of the interior space is further dramatized by the close presence of the timber masts that fill the interior as if the space itself were carved out of the wood to dissipate mass. 
Christian Norberg-Schultz describes how the timber post becomes an extension of the energy of the frame as opposed to the static resistance to the forces of gravity reflected by the stone column (8). The braced timber frame, as opposed to the horizontal log construction, provided Norwegian church builders with a technology that could support the ambition of the age "to dissolve architecture from the substantial to the insubstantial..." (Summerson10).

Exposing the timber frame on the church interior allows each of the timber fir wood members to be recognized both as separate elements and simultaneously as one of a host of integral parts of a structure contributing to the realization of a vision where there is a unity in the overall construction. The exposed frame offers the architecture both a symbol of and the presence of visual harmony.

In southern Europe from about 1225 onward Gothic aedicular architecture was stressed and exaggerated principally by the liberal use of gables (Summerson18). In the fully developed stave church, such as the church at Heddal, the form with its cluster of roofs is further elaborated by the inclusion of additional gables, crosses and dragonheads. At Heddal the composite roof, top-heavy with gables, appears to hover over the ambulatory arcade with the gables appearing from afar as though "suspended from the clouds and have just been drawn into place by flying monsters..." (Summerson 21).

The influence on the Norwegian stave-church of the masonry architecture of southern Europe can also be seen in the transfer and transformation of elements such as the 'dwarf arcade' and the apse. Curved elements were alien to the constructional logic of timber construction and were difficult to transfer to wooden churches. To achieve the curved forms horizontal members for the curved walls of the apse, upper roofs and turret for example required curve-grown timbers to be specially sourced and worked (Gjone D7).

\section{Timber frames in the nineteenth century Anglican churches}

Six centuries later, exposing the timber frame on the exterior walls of the $19^{\text {th }}$-century Anglican church was intended to express the church-like qualities of medieval architecture (Scott 19). These qualities were proposed to be transferred from medieval church building and medieval English, half-timbering technology (Scott 23).

Although the preferred material for $19^{\text {th }}$-century Anglican church walls was stone masonry a lack of funds and speed of settlement, led to the widespread erection of shed-like, wooden churches particularly in colonies where timber was readily available and masonry skills were scarce.

In 1849, the Ecclesiologist published Rev. William Scott's paper, "On Wooden Churches", praising wood as material for church construction and tracing its ancient origins and transformations. Scott argued that the "colonnade and pediment, however gorgeous, is nothing elementarily, as has been often shown, but a row of wooden posts thrust into the earth, with a roof of timber logs triangularly imposed upon them," and, "then in every church, however gorgeous, we may still recognize the original wooden idea, which was the primary one." (15).

Whilst the Ecclesiologists had a clear preference for stone churches that conformed "with what they called the 'middle-pointed' phase of English Gothic" - i.e. about 1320-1350 (Summerson164) the mid-19 ${ }^{\text {th }}$ - century surge in the number of colonial Anglican diocese and parish churches throughout the world increased the efforts of the Ecclesiologists to find designs that could address the problems of church design for non-English conditions such as a tropical or freezing climates, where there was readily-available timber (Scott 23).

With the urgency to house expanding congregations colonial parish churches were speedily erected in timber. These were often built as a cheap and temporary 'god box' - an unornamented, stud-framed shed with a single, gabled roof - far from one of the "graceful, reserved essays on the approved $14^{\text {th }}$ - century theme" (Summerson164).

The desire by the Ecclesiologists to find suitable models for timber churches included a search for medieval precedents. Scott's paper lists the features of the Middle Pointed Gothic church and proposes that: "For all the essential parts of a church we have actual examples in wood." (19). The medieval precedents Scott identifies for timber walls are "the two churches of Greenstead and Nether Peover together with the strange Norwegian fabric" (19). The technique for constructing the half-timbered wall, such as at Nether Peover, was to erect the timber framework with posts, beams and diagonal bracing and to fill spaces in between with plaster. Because half-timbered walls constructed in frost prone areas of North America tended to 
deteriorate as the plaster cracked Scott proposed church walls be built entirely of wood like the proto-stave-church at Greenstead (Scott 23).

Scott's descriptions of the medieval Norwegian stave-church closely follow those of the paper titled "Primitive Churches of Norway" printed a few years earlier in Weale's Quarterly Papers (which also printed a review including stave-churches in 1844). Having described the Norwegian stave-church Scott proceeds to recommend features of the stave-church for the design of the late $19^{\text {th }}$-century wooden church with the following reservation about the stavechurch clerestories: "They interfere, I think, with that subdued humility, that retiring and unpretending dignity which ought to characterize a wooden church."(25).

Scott describes the contemporary wooden churches in the "North American provinces" as exemplifying "almost every error which is possible to make in such a building." (20) and divides the churches into two construction types; the frame church and the log church (20). "It is obvious" he writes, "that the prevalence of flat horizontal lines in both the frame church and the log church is fatal to the great principle of Christian architecture, its verticality." (23).

Around the same time as these discussions about medieval precedents for colonial timber churches were being printed in England, Bishop Selwyn in New Zealand was building the chapel at St John's College, Tamaki, consecrated 1847 and attributed to architect, Frederick Thatcher. The chapel, with its hipped and gabled roofs, has walls with an exposed structural frame patterned by horizontal and vertical members with curved timber braces and the vertical planks fixed to the inner face of the frame. To accentuate the expression of the structure as a skeletal frame the vertical timber boards were originally treated only with a clear linseed oil in contrast to the frame that was rendered darker by oil tinted with umber (Mane-Wheoki 79.)

Whilst it is possible that the adoption of the exposed frame derives from half-timbered domestic architecture in England or the pattern book of 'picturesque design' Village Architecture, as proposed by Mane-Wheoki (78), the impetus is fundamentally a desire to exploit the expressive capacity of the construction for its architectural potential to revive medieval precedent.

One of the more architecturally expressive re-interpretations of the stud wall as "outside studding" was adopted in 1865 by the architect, Richard George Suter soon after his arrival in Queensland where he is credited with being the first to use the technique (Watson 28).

Suter's first church design in Queensland, St Andrew's Church at Lutwyche (dedicated November, 1866), was published in the Illustrated London News $4^{\text {th }}$ May 1867 . Here the single thickness wall, sanctioned by a relatively mild climate, was constructed of diagonally laid tongue and groove boards in a light coloured finish with dark stained hardwood frame of vertical and horizontal framing members with diagonal bracing.

Suter's use of the exposed frame for expressing Gothic Revival ideals in timber church architecture are highly likely to have been influenced by the Selwyn churches discussed in the ecclesiologist and familiar to his brother A.B. Suter consecrated Bishop of Nelson in August 1866.

\section{Timber frames in the architecture of Andresen O'Gorman}

Curiously the exposed timber frame has not become widely used for contemporary interpretation, but one that Andresen O'Gorman Architects developed in their architecture. The practice has from time to time been asked if their projects are influenced by traditional Japanese architecture, Norwegian stave-churches or perhaps Suter's Queensland work. Whilst research interests and background clearly play their part the architects propose that a superficial, visual resemblance can be generated by the shared technology of the exposed timber frame.

In the architecture of Andresen O'Gorman the primary frame of many of the buildings is constructed from Australian hardwood, a common, regional building material. Eucalyptus and its material properties have in turn prompted architectural intentions - particularly those ideas that explore the expressive capacity of construction and the potential for interaction with the natural environment.

Malouf describes the timber houses in Brisbane as: "Open wooden affairs, they seem often like elaborated tree-houses, great grown-up cubby-houses hanging precariously above ground" (261). The experiential qualities, the material and the diagram of the simple Queenslander house, with its set of rooms surrounded by a fringe of timber posts forming thresholds to the landscape, offers potential for variety and interpretation and is a recurring reference in the work of Andresen O'Gorman. 
Another reference relates to the idea of 'harmonia' the word for harmony that in Ancient Greek simultaneously means two things: One meaning is what we generally understand harmony to be, an arrangement of related elements such as colours, proportions and sounds that make a pleasing pattern (Fletcher 9). Its other meaning is a three-dimensional frame of timber, in joinery or fine carpentry, like the frame of a table "such that to take one member away would cause the whole to collapse." (Fletcher 9). This meaning predates the former and probably goes back to Neolithic times. It is a beautiful, physical symbol of the later more abstract meaning. No doubt the 'captured' space that offers a place within the frame presents a powerful phenomenon to the human psyche, but it also hints at the reverence in which the ancients held the conceptual solution where the interconnection of parts made a total unit. The later, Homeric, meaning of the word 'harmonia' is given as; 'that which binds together as a unity' (Guthrie 220). Again, the meaning can be either physical or abstract and demonstrates the significance to the ancients of ideas and concepts which they saw as mutually interpretative to both.

Maria Karvouni accents a similar theme in her essay "Demas: The Human Body as a Tectonic Concept". She explains how the Ancient Greek word for buildings, 'demos', was the historical derivative of 'demas' which means; 'the human mind and body as a unity' (111).

In Greek architecture 'harmonia', the binding together of the whole, was sought simultaneously in the physical jointing of the parts of the building as well as the interlocked proportional systems - the binding lines of geometry (Karvouni 112). Karvouni raises many interesting matters and two of these offer important distinctions. Firstly that it is in the hard material (the stuff of building as opposed to the soft shaping of paint or clay) that 'demas' was found (Karvouni 106). Secondly, the building, through its tectonic concept, was seen to embody and integrate qualities of life and nature through the relationship between physical commodities (Karvouni 118).

The work of Andresen O'Gorman has been informed by eucalyptus timber and its role in Australian architecture. The Australian timber stud frame is a derivative of the British version developed for use with northern hemisphere, mainly Norwegian, softwoods (Bell 84). Imported into Australia and adapted for use with low-grade hardwoods, this framing technique gained popularity in Queensland after the Second World War particularly for use with plantation softwoods.

The timber stud frame system is based on non-durable timbers being protected inside sheeted walls of durable or finishing sheet materials. The visual expression in a building therefore is of the sheeting and not the tectonic form - such as the frame itself. The continued use of this convention has masked opportunities offered by the more durable, local, eucalyptus timbers. This framing technique also limited the architectural opportunities for developing abstract expression and poetical concerns for 'place'.

The inherent toughness of Australian hardwoods usually requires that they be used while still 'green', at high water content, for easier workability. Cut from logs with a pronounced spiral growth and a high variability of moisture from heartwood to sapwood, the material continues to dry - usually while held in the building. Eucalyptus hardwood remains an active material after the construction has occurred. The timber is subject to inconsistent shrinkage, warping, twisting and cupping across the grain. This has traditionally been the criticism of hardwood for building construction. Because of its material strength eucalyptus timber permits the use of relatively small sections approximating the visual expression of steelwork. Unlike northern hemisphere softwoods with their larger sections Australian hardwoods offer the opportunity of assembling a framework of 'slim-line' timber members.

A tactic Andresen O'Gorman employ is that of simple lamination; forming components out of pairs of members, matched in opposing grain formation and so setting the movement of one component against the other to counteract warping and twisting. This strategy goes back to the house at Redbank Plains (1970) and is used in later work such as the Mooloomba House (1995-00).

Having 'tamed' the material in this way it can be freed from being hidden inside the stud wall. Exposed to take advantage of its durability and strength the hardwood is available to contribute to the expressive form of the building in which it can play such a physical part. With the release of the timber frame from its concealment in the stud wall a number of architectural opportunities become possible such as; to reveal the visual dynamic of the parts related to the whole; to offer visual patterning to the skeletal structure for geometrical order and proportioning; to create continuity and intensify spatial interaction through constructing transparency in relation to 
landscape, establish formal character and to develop metaphors including 'nests' and 'wooden caves'.

\section{Conclusion}

In summary, the timber frame is shown to be significant as the medium of transfer of architectural intentions in each of the three examples - in the medieval Norwegian basilica stave-church, in R.G. Suter's nineteenth century Anglican wooden churches and in the contemporary timber buildings of Andresen O'Gorman.

Whilst the church buildings express conventional church-like qualities and the house in part expresses conventional domestic shelter the architectural expressions rely essentially on a basic characteristic of the exposed timber frame - one that allows it to play a leading role in the transfer and transformation of intentions.

Exposing the timber frame on the interior and/or exterior of the structures is seen to release its matrix of timber members and its capacity to contribute architectural expression to buildings. The matrix, forming 'lines' in space, has an expressive potential that includes the capacity to delineate proportion, direct eye-movement, suggest spatial enclosure, create patterning, permit transparency and establish continuity with landscape. These expressive opportunities have been developed, to some extent, in the architecture of all three buildings.

This fundamental understanding led architects to amplify the visibility of the timber frame and particularly to highlight the visual harmony that results when the parts can be seen to contribute to the unity of the whole.

\section{References}

Bell, Peter. "Stud Framing: The Empire Strikes Back". Architecture Australia Mar 1987: 81-84.

Bugge, Gunnar. and Norberg-Schulz, Christian. Stav og Laft I Norge. Oslo: Byggekunst Norske Arkitekters Landsforbund, 1969.

Downs, Barry. Sacred Places: British Columbia's Early Churches. Vancouver: Douglas and Mclntyre, 1980.

Fletcher, Rachel. "Proportioning Systems and the Timber Framer." Timber Framing: Journal of the Timber Framing Guild Dec 1990: 8-9.

Gjone, Erling. "D1, Stavkirkene I Norge”. Utdrag av Forelesninger I Byggekunst V. Trondheim: Arkitektavdelingen NTH, 1965.

Guthrie, W.K.G. "The History of Greek Philosophy". The Earlier Presocratics and the Pythagoreans Vol 1. Cambridge: Cambridge UP, 1962.

Karvouni, Maria. "Demas: the Human Body as a Tectonic Construct". CHORA Vol 3 (1999) 103-124.

The Growth of Lutwyche Parish. Brisbane: Lutwyche Parish, 1951.

Malouf, David. "A First Place: The Mapping of a World”. Johnno, Short Stories, Poems, Essays and Interviews, Ed. James Tulip. Brisbane: University of Queensland Press, 1990.

Mane-Wheoki, Jonathan. "Selwyn Gothic: The Formative Years". Art New Zealand 54 Autumn (1990): 76-81.

Norberg-Schulz, Christian. Treverk. Oslo: Arkitekturhefte 1 Trelastindustriens Landsforening, 1998.

Scott, William. "On Wooden Churches." The Ecclesiologist 1849, 14-27.

Summerson, John. "An Interpretation of Gothic." Heavenly Mansions and Other Essays on Architecture. New York: Norton, 1963.

Summerson, John. "William Butterfield; or the Glory of Ugliness", Heavenly Mansions and Other Essays on Architecture, New York: Norton, 1963.

Watson, Donald. "Outside Studding 'Some claims to architectural taste." Historic Environment V1 2,3 (1988) 22-31. 


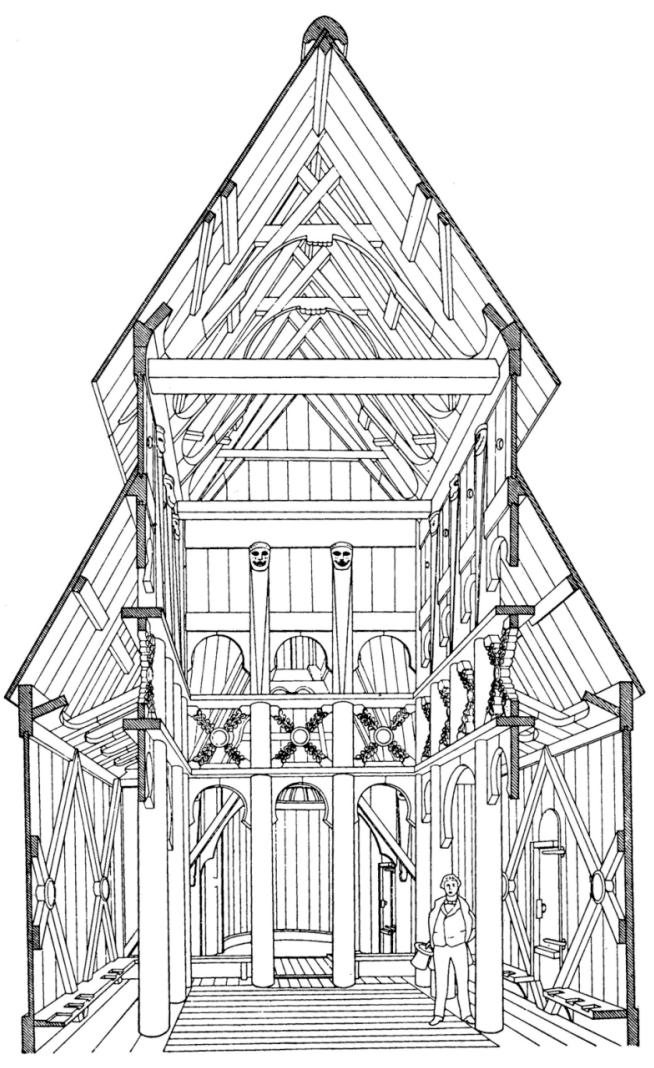

Fig 1

Perspective drawing: Stave-church at Borgund.

Bugge, Gunnar. and Norberg-Schulz, Christian. Stav og Laft I Norge. Oslo: Byggekunst Norske Arkitekters Landsforbund, 1969: 152.

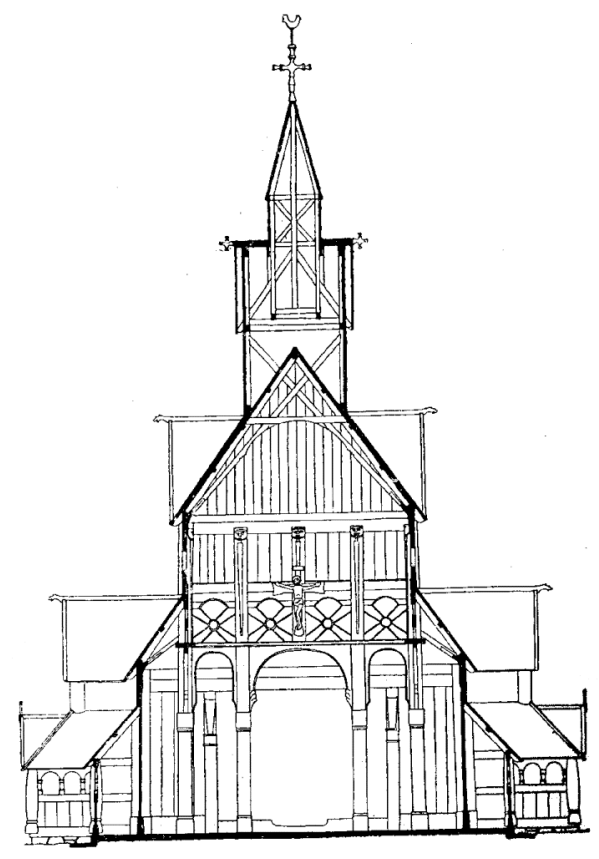

Fig 2

Section: Stave-church at Heddal.

Bugge, Gunnar. and Norberg-Schulz, Christian. Stav og Laft I Norge. Oslo: Byggekunst Norske Arkitekters Landsforbund, 1969: 166. 


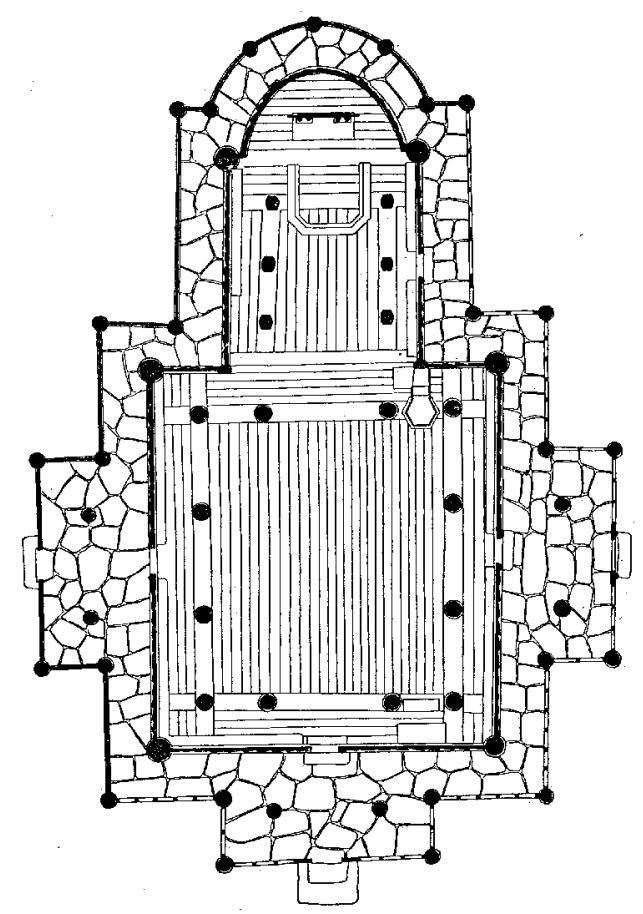

Fig 3

Plan: Stave-church at Heddal.

Bugge, Gunnar. and Norberg-Schulz, Christian. Stav og Laft I Norge. Oslo: Byggekunst Norske Arkitekters Landsforbund, 1969: 166.

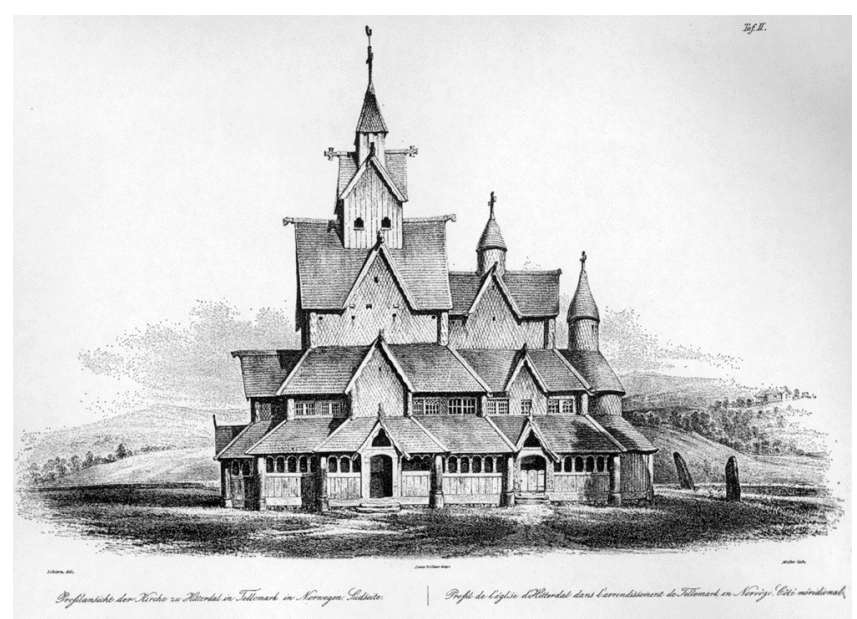

Fig 4

Schiertz (1837), Profilansicht der Kirche zu Hitterdal in Telemark in Norvegen Sudseite. Lithograph after drawings of stave-church at Heddal in Hitterdal.

Bugge, Gunnar. and Norberg-Schulz, Christian. Stav og Laft I Norge. Oslo: Byggekunst Norske Arkitekters Landsforbund, 1969: 168. 


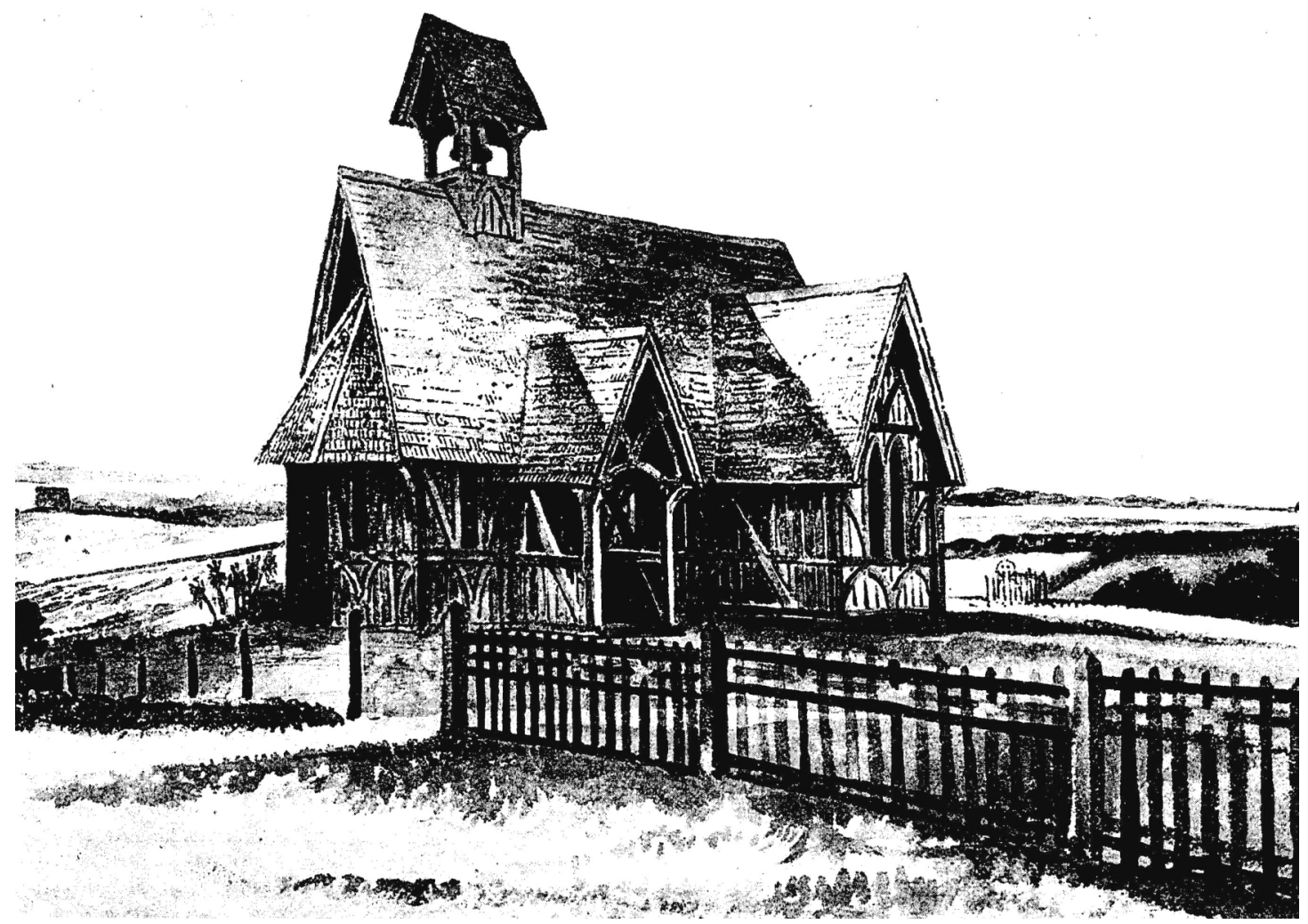

Fig 5

John Kinder, The Chapel, St. John's College near Auckland. Monochrome wash. Photograph: Alexander Turnbull Library, Wellington.

Mane-Wheoki, Jonathan. "Selwyn Gothic: The Formative Years". Art New Zealand 54 Autumn (1990): 80.

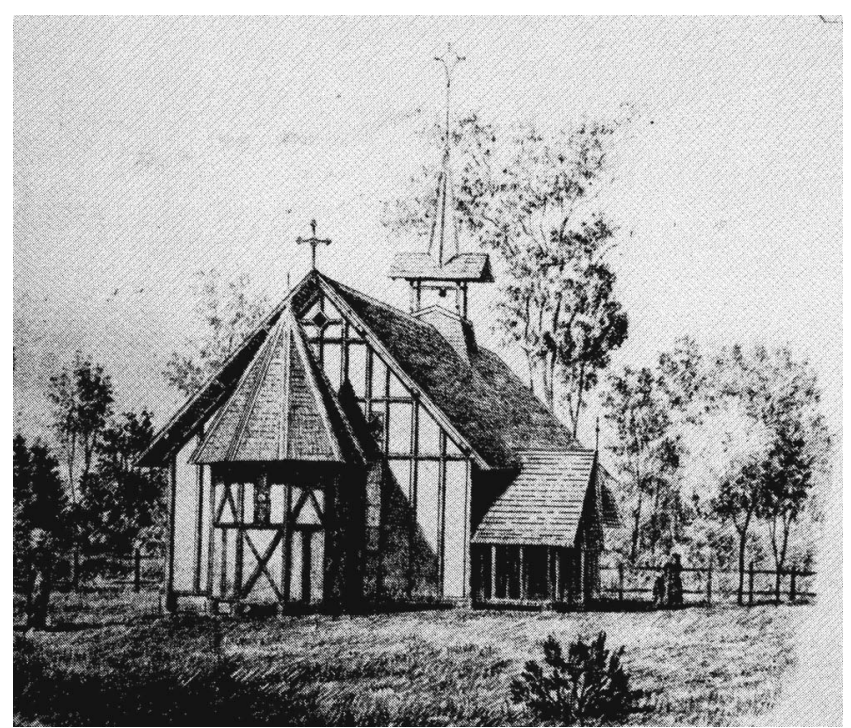

Fig 6

Richard G. Suter, St Andrew's Church, Lutwyche.

Photograph: Lutwyche Parish Archives, Brisbane. 


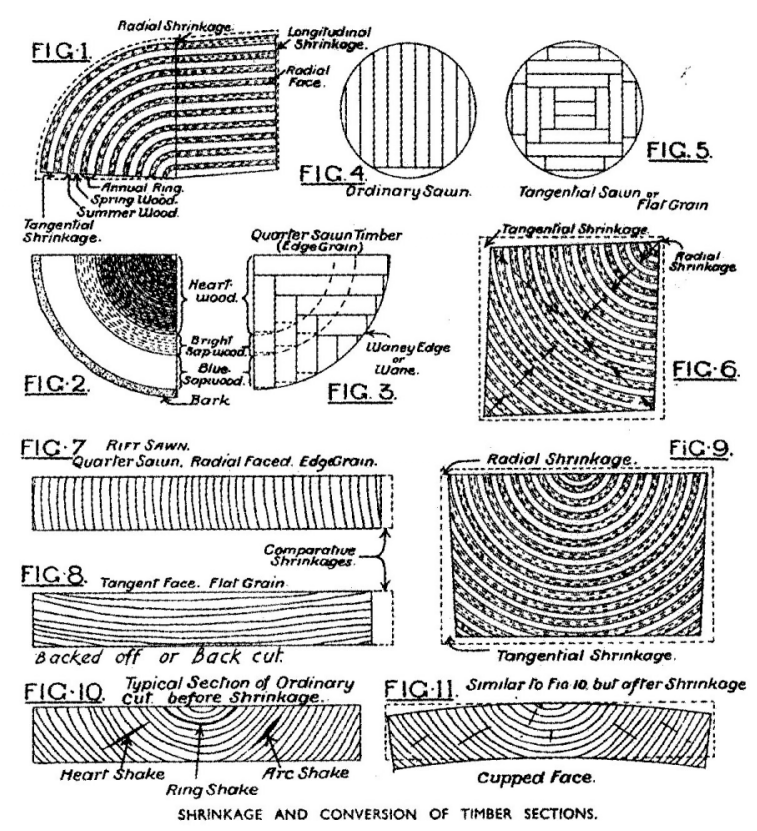

Fig 7

"Shrinkage and Conversion of Timber Sections", Architecture, Jun 1934.

"Rhetoric and Tone" by Naomi Stead and Paul Hogben, Architecture Australia. Vol 936 Nov-Dec. 2004: 26.

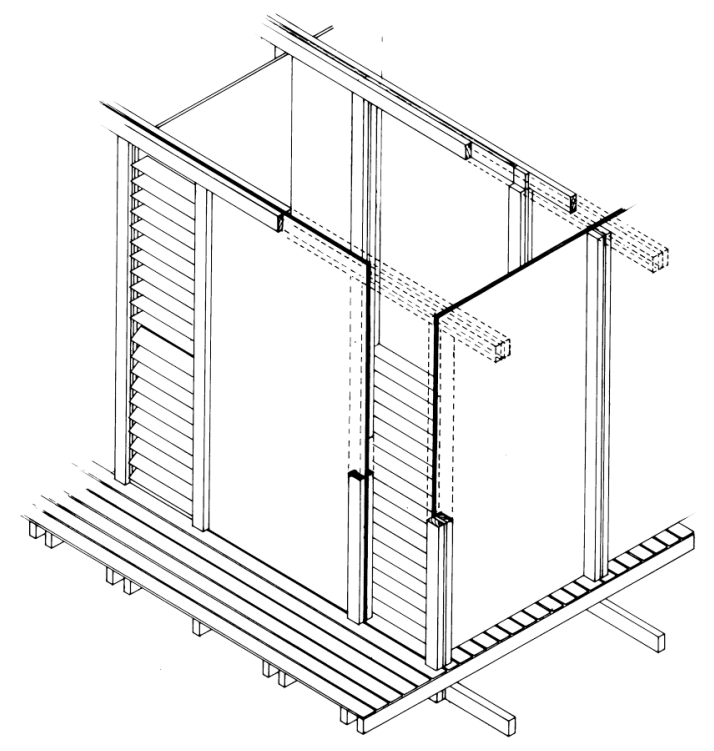

Fig 8

Andresen O'Gorman Architects, Mooloomba House wall detail. Axonometric. 


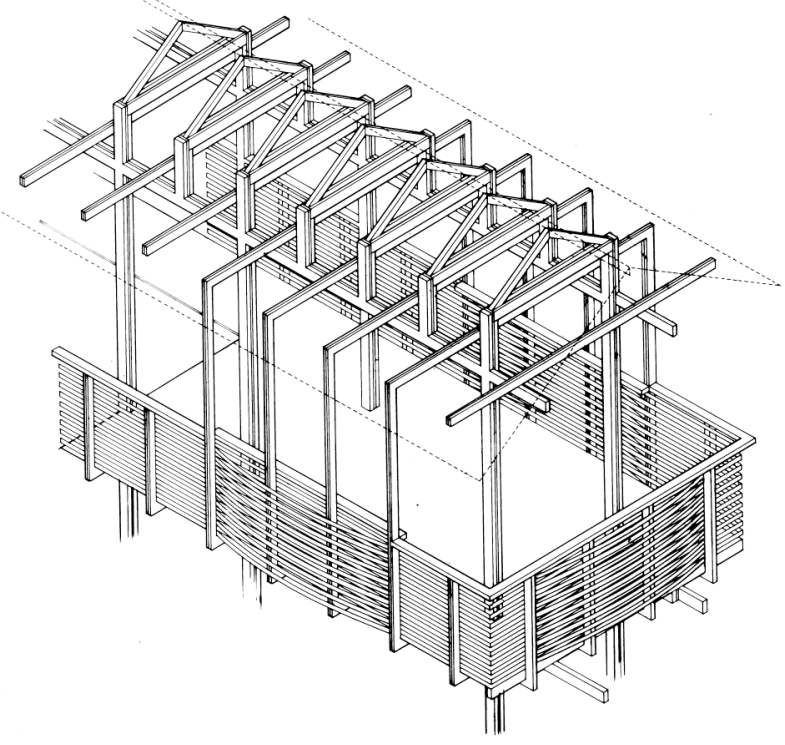

Fig 9

Andresen O'Gorman Architects, Mooloomba House roof detail. Axonometric.

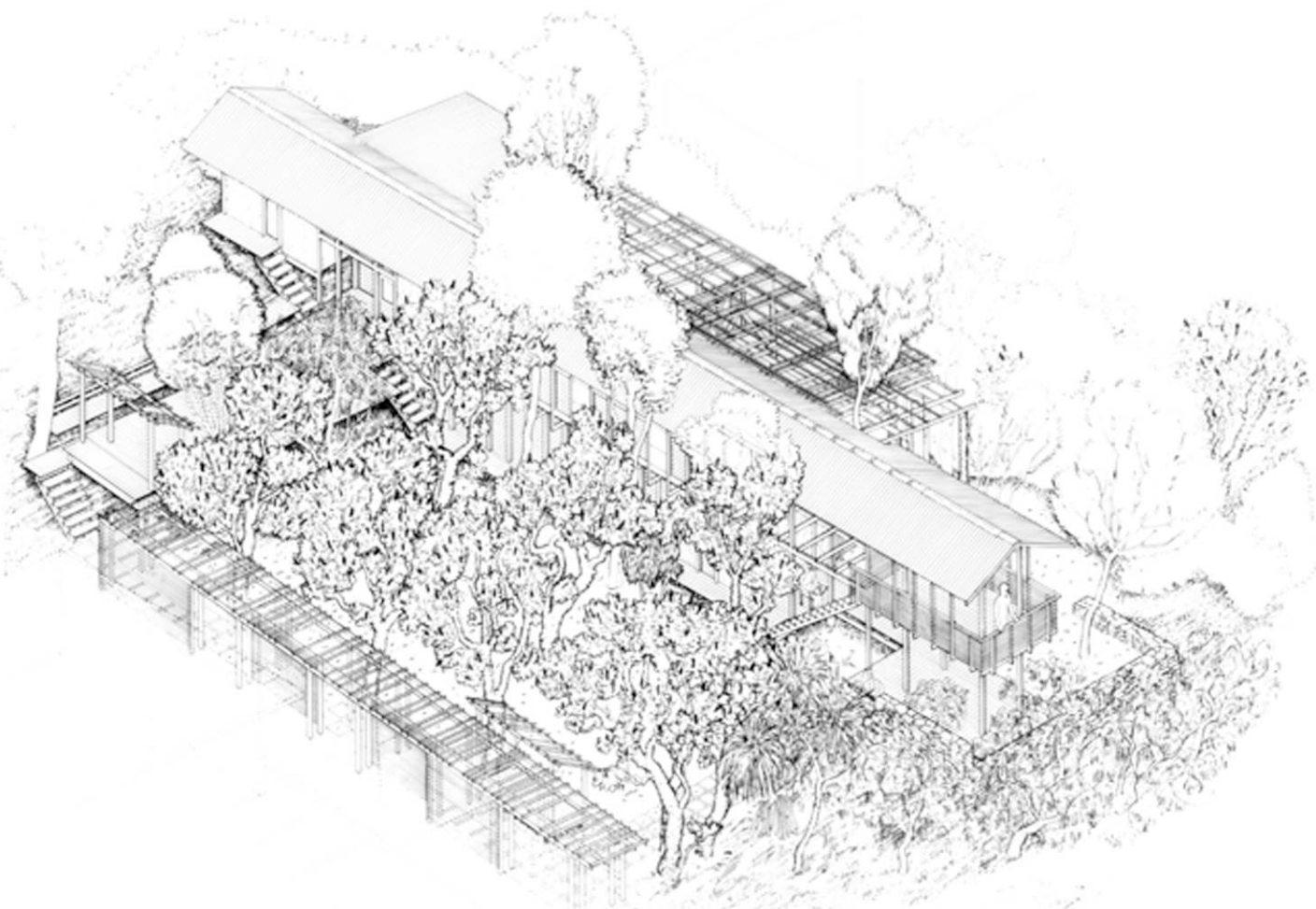

Fig 10

Michael Barnett, Mooloomba House. Axonometric. 